\title{
Language practices of the Romani community in Serbia: Inclusion or response to the stigma?*
}

\author{
J. Petrović \\ University of Niš \\ Ćirila and Metodija, 2, Niš, Serbia, 18000 \\ (e-mail: jasminafilfak1@gmail.com)
}

\begin{abstract}
The results of the research presented in the article are part of the findings of the study conducted in 2014 within the project Social and Cultural Potential of the Romani Ethnic Community in Serbia. The survey was based on the stratified sample of 1,212 respondents and conducted by a team of researchers representing four universities of Serbia. One of the aims of the research was to identify the prevailing language practices of the Romani community in Serbia. The paper presents the results of the study of the attitudes of the Romani to the use of language and their language practices focusing on such issues as the assessment of the importance of the Romani language in expressing their identity, the use of the Romani language in everyday communication in various social contexts, and the estimates of the significance of this symbolic capital in education as expressed in the parents ideas and attempts to ensure that their children are educated in their mother tongue. The results of the survey proved that the Romani community's attitudes to language and language practice are an expression of the general social position of this group, i.e. a minority ethnic group in the Serbian society. Therefore, its language practices are determined by the need to preserve the Romani community's identity and by uneven distribution of social power between majority and minority communities. Thus, social power (or powerlessness) ensures legitimacy for the use of a specific language in certain social situations. Considering the Romani ethnic community, the use of the mother tongue is reduced to the domain of private communication with some of the Romani people renouncing the use of their native language and hiding their ethical identity. The study proves that linguistic mimicry serves as a way to avoid social stigmatization.
\end{abstract}

Key words: Serbia; Romani; language practices; identity; inequality; stigmatization; inclusion

Being a part of the cultural tradition of the largest pan-European minority, the culture of the Romani in Serbia has certain universal elements determined by a mixture of historical, political and economic factors including the influence of intercultural exchange. Therefore, the Romani worldview is not "based on archaic images brought from the homeland" [6]. However, cultural identity of the Romani in Serbia including language practices cannot be separated from the micro- and macro-social-cultural milieu of Romani communities today. The Romani as a social group are characterized by cultural, social, religious and residential diversity $[5 ; 18]$, and by exceptional social mimicry and relative closeness, which are not only a reaction to social isolation but also a way of "protecting group identity and preserving group order and structure" [18. P. 8].

* (C) J. Petrović, 2019.

The article is a part of the project No 179013 supported by the Ministry of Education, Science and Technological Development of the Republic of Serbia.

The article was submitted on 14.02.2019. 
For decades, key features of their social position in Serbia are spatial segregation, extremely unfavorable educational structure and a high share of illiterate, unemployment or low paid and stigmatizing jobs, a low level of inclusion in health and social care systems, lack of political participation, public action and international organization [14. P. 815; 20. P. 1139]. Moreover, the population of Serbia preserves social distance and stereotypes about the Romani as a 'sub-class' [11 - 13] with negative patterns (dirty, lazy, primitive, prone to theft, etc.) [16].

Thus, it is not surprising that there are certain unwritten rules in social interaction between the Romani community and representatives of other ethnic groups, which prove the existing boundaries between the Romani and non-Romani people. A set of rules known as Romanipe(n) constitutes a system of social-cultural norms and the basis of the Romani identity [4], and the Romani language is an important element of belonging to the community. The totality of these characteristics together with the social practices of the majority of the Romani group determined the fact that the Romani in Serbia (and many other countries) lack resources for preserving ethnic and cultural identity and for social integration (assimilation). Besides education, we mean preserving one's language and good knowledge and use of the official language of the majority.

The preservation of the mother tongue by the Romani community cannot be motivated only by the need to preserve one's ethnic peculiarity for the Romani community as not having its own state and institutional mechanisms for supporting cultural and linguistic identity needs its own language to stay an ethnic community. However, the use of languages is not just a linguistic or cultural issue but also a reflection of the social position of a minority ethnic group within the majority with another official language, within other language practices considered legitimate. Therefore, in the field of language use, according to P. Bourdieu, there is symbolic domination reflected in the fact that 'nonstandard' speakers are forced to apply the criteria of the dominant group to assess their own language practices. Minority communities, especially not good in dominant 'legitimate' language, must make special efforts to study, otherwise they can feel a kind of linguistic insecurity or tension [2. P. 70]. Social researchers often miss the fact that language practices should be studied in the social-historical and political context, i.e. considering issues of power, inequality and language policies [7. P. 441]. Although an average language user can be unaware of this context, sociologists must not ignore it; therefore, we study the language practices of the Romani in Serbia as a reflection of their social power (or lack of it).

The research was conducted by the Sociology Departments of the Faculty of Philosophy in Novi Sad, Faculties of Philosophy in Niš and Belgrade, and the Department of Social Sciences of the Faculty of Mechanical Engineering in Niš with the help of representatives of the Romani community. The survey was conducted on the stratified sample based on the results of the last census in Serbia and regional distribution of the Romani in Serbia (29\% live in Vojvodina, 18\% — in the Belgrade region, $14 \%$ in Šumadija and Western Serbia, and 39\% — in Eastern and Southern Serbia.). The sample of 1,212 respondents constitutes $0.82 \%$ of the Romani population in Serbia. The survey was conducted in 34 municipalities with the highest shares of the Romani 
in population. Special attention was paid to the residential aspect as reflecting the integration of the Romani into the majority: all areas were divided into urban/rural microregions, Romani settlements (mahalas) in cities/villages, slums in cities/villages, mahalas or slums outside cities/villages, and suburban settlements. The survey was based on the questionnaire focusing on assessing the importance of the Romani language for the Romani, their attitude to learning Serbian, their desire to educate their children in the Romani language, etc.

In cultural interaction with other ethnic communities, the Romani receive more than they give in terms of the elements of culture [15. P. 23] due to their cultural identity and social position. Such a tendency is expressed, inter alia, by the peculiarities of their linguistic identity: the Romani culture is predominantly oral, and the Romani language remains a mixture of its different versions with the language of the majority. Despite the linguists' increasing interest in the Romani language and its standardization, they reveled "a rather bad knowledge and poor use of the Romani language in everyday life, ... and the consequence of this is a gradual disappearance of the Romani language" [8. P. 21-22]. The question is whether the language of the Romani community is more important in preserving cultural and ethnic identities that the languages of other nations due to the fact that the Romani do not have a state and traditional cultural and linguistic means of preserving their identity. Therefore, it is important to know whether the Romani in Serbia recognize the importance of language for preserving one's ethnos and culture, and we asked "What makes the Romani community special" to find out how the Romani perceived the role of their native language in preserving their collective identity. The data show that the Romani consider their music, mother tongue and customs as three key bases of ethnic identification (Table 1). The mean values of the estimates of the ethnic identity elements prove that the Romani consider language one of the most important features of their ethnic community.

Despite the Law on the Protection of the Rights and Freedoms of National Minorities [10] saying that "members of national minorities can freely use their language and writing privately and publicly", a quarter of the Romani in Serbia do not speak Romani well or at all. It is particularly interesting that every twelfth respondent $(8.3 \%)$ neither speaks nor understands Romani. The Romani who do not know Romani usually live in Vojvodina (17.2\%), Šumadija and Western Serbia (13\%), less often in the Belgrade region $(8.1 \%)$ and never in southeastern Serbia. There is a statistically significant difference between residents of northwestern and southeast Serbia considering the knowledge of Romani.

Table 1

evaluate what makes your community special"

\begin{tabular}{|l|c|c|}
\hline \multicolumn{1}{|c|}{ Answers } & Mean & Median \\
\hline Romani language & 4.09 & 5.00 \\
\hline Tribal affiliation & 2.89 & 3.00 \\
\hline Romani customs & 3.98 & 5.00 \\
\hline Romani music & 4.32 & 5.00 \\
\hline Romani clothing & 2.72 & 3.00 \\
\hline Romani cuisine & 2.82 & 3.00 \\
\hline Part of the settlement where the Romani live & 3.40 & 4.00 \\
\hline
\end{tabular}


There is also a statistically significant difference among respondents with different levels of education. Respondents without education or with the lowest level of education know Romani better as compared to those with higher education levels. Probably, the Romani who study for a longer time adopt the culture of the dominant group, and the education system is a factor of acculturation or even assimilation by means of the legitimate language. Likewise, the residential factor affects the use of the language of the majority by a certain mechanism: the higher the concentration of speakers of the standard language the lesser the tolerance to the use of stigmatized language and of other languages representing stigmatized groups. In other words, in the southeast of the country with many language varieties of Serbian, there is lesser pressure on speakers of non-standard varieties and from marginalized groups to use the standard language. And in the economically more developed parts of Serbia, the Romani have the opportunity to work with the majority population more often, which leads to the necessity to learn Serbian. The Romani living in southeastern Serbia are less frequently employed compared to other regions.

Romani respondents whose mother tongue is Romani speak it excellently in $88.9 \%$ of cases, unlike the Romani whose mother tongue is Serbian or other language (respectively, only every fifth or third speaks Romani excellently). A third of the Romani in Serbia with the Serbian mother tongue neither speak nor understand Romani, and 43.8\% of those whose mother tongue is different (as a rule, Romanian) neither speak nor understand Romani. Thus, despite the great declarative importance of Romani for the Romani community and culture, in fact it partly forgets its native language. The question is whether in Serbia there are really $15.4 \%$ of the Romani whose mother tongue is Serbian (descendants of ethnically mixed marriages) and 6\% with another mother tongue, or this is a kind of social-cultural mimicry.

It is known that the Romani often declare themselves Serbs, Yugoslavs, etc. in the census, and in the survey the language of the majority was named as 'mother' tongue (Table 2). In other words, the specific position of the marginalized ethnic group imposes a rational choice of declaratively accepting the language of the dominant ethnic group as a mother tongue to avoid social stigmatization: $63 \%$ of respondents said that they knew Romani people who do not recognize their nationality and present themselves in some other way so that to be accepted by the society $(55.7 \%)$ or to ensure personal achievements $(34.9 \%)$. It should be noted that other studies also revealed such social mimicry due to the fact that members of the Romani community have suffered discrimination and marginalization: "in such circumstances, members of the Romani community do not want to openly name their ethnicity or tend to name themselves as members of the dominant community to avoid possible problems" [2. P. 23]. Some authors argue that "a large number of Romani families who managed to get out of poverty, to change their place of residence or in any other way to succeed, often refuse to be identified as Romani" [9. P. 41].

The data are even more interesting when the prevailing language practices in everyday communication are considered. In general, the mother tongue is used (always/often) in private interaction: the majority use their mother tongue in communication with parents $(72 \%)$, spouses $(71.2 \%)$, relatives $(67.3 \%)$ and children $(65.6 \%)$, but not with neighbors, friends, colleagues or people outside the close social circle (Table 3 ). 
“Do you speak Romani?” (distribution by mother tongue)

\begin{tabular}{|l|c|c|c|r|}
\hline \multirow{2}{*}{ Answers } & \multirow{2}{*}{ \% in the sample } & \multicolumn{2}{c|}{ Respondents' mother tongue } \\
\cline { 3 - 5 } & & Serbian & Romani & Other \\
\hline Yes, excellently & 74.9 & 21.0 & 88.9 & 30.1 \\
\hline Yes, but poorly & 10.8 & 26.3 & 7.9 & 8.2 \\
\hline No, but I understand it & 6.0 & 19.9 & 2.4 & 17.8 \\
\hline I neither speak nor understand it & 8.3 & 32.8 & 0.7 & 43.8 \\
\hline
\end{tabular}

Use of the mother tongue in different situations, \%

\begin{tabular}{|l|c|r|r|r|}
\hline \multicolumn{1}{|c|}{ Communication with: } & always & often & rarely & never \\
\hline spouse & 71.2 & 14.4 & 7.3 & 7.2 \\
\hline children & 65.6 & 16.3 & 11.7 & 6.4 \\
\hline parents & 72.0 & 14.8 & 7.2 & 6.0 \\
\hline relatives & 67.3 & 20.5 & 9.1 & 3.1 \\
\hline neighbors & 51.5 & 21.7 & 16.7 & 10.0 \\
\hline friends & 47.5 & 23.7 & 20.7 & 8.2 \\
\hline colleagues & 22.5 & 9.6 & 20.1 & 47.8 \\
\hline other people & 17.5 & 8.8 & 24.6 & 49.1 \\
\hline
\end{tabular}

Use of the mother tongue in different situations by the mother tongue of respondents, \%

\begin{tabular}{|l|c|c|c|c|c|c|c|c|c|c|c|c|}
\hline \multirow{2}{*}{$\begin{array}{c}\text { Communica- } \\
\text { tion with: }\end{array}$} & \multicolumn{3}{|c|}{ always } & \multicolumn{3}{c|}{ often } & \multicolumn{3}{c|}{ rarely } & \multicolumn{3}{c|}{ never } \\
\cline { 2 - 16 } & $\mathrm{S}$ & $\mathrm{R}$ & $\mathrm{O}$ & $\mathrm{S}$ & $\mathrm{R}$ & $\mathrm{O}$ & $\mathrm{S}$ & $\mathrm{R}$ & $\mathrm{O}$ & $\mathrm{S}$ & $\mathrm{R}$ & $\mathrm{O}$ \\
\hline spouse & 89.3 & 68.3 & 68.3 & 5.9 & 16.7 & 3.3 & 4.6 & 7.8 & 6.7 & 0.0 & 7.3 & 21.7 \\
\hline children & 88.9 & 62.2 & 59.3 & 5.6 & 18.6 & 8.5 & 5.6 & 12.7 & 11.9 & 0.0 & 6.4 & 20.3 \\
\hline parents & 87.6 & 69.1 & 67.6 & 5.9 & 17.1 & 9.9 & 5.4 & 7.4 & 9.9 & 1.1 & 6.5 & 12.7 \\
\hline relatives & 87.1 & 63.4 & 67.1 & 9.1 & 23.3 & 13.7 & 2.2 & 10.2 & 12.3 & 1.6 & 3.1 & 6.8 \\
\hline neighbors & 83.3 & 45.8 & 43.1 & 8.6 & 25.3 & 8.3 & 6.5 & 17.6 & 31.9 & 1.6 & 11.2 & 16.7 \\
\hline friends & 85.5 & 40.5 & 39.7 & 9.1 & 27.1 & 16.4 & 4.3 & 23.7 & 23.3 & 1.1 & 8.7 & 20.5 \\
\hline colleagues & 82.9 & 10.4 & 16.7 & 5.9 & 10.0 & 13.6 & 2.9 & 23.8 & 18.2 & 8.2 & 55.8 & 51.5 \\
\hline other people & 85.9 & 4.5 & 11.0 & 3.3 & 9.9 & 8.2 & 4.3 & 27.9 & 34.2 & 6.5 & 57.7 & 46.6 \\
\hline
\end{tabular}

$\mathrm{S}-$ mother tongue is Serbian; $\mathrm{R}-$ Romani; $\mathrm{O}-$ other language.

Although the ranking of the frequency of the use of the mother tongue remains the same, the Romani who named Romani as their mother tongue use it less often in all mentioned communication situations, i.e. there are the Romani who never use their mother tongue in their family, with relatives, neighbors or friends (Table 4). More than a half of the Romani whose mother tongue is Romani have never used it in communicating with colleagues and people outside their close social circle (and the differences in the language practices of speakers with different mother tongues are statistically significant in all communication situations).

There are also statistically significant differences in language practices among the Romani by the regions of Serbia they live in. The best 'guardians' of mother tongue are the Romani from the south and southeast of Serbia, while the Romani living in the Belgrade region, Vojvodina, Šumadija and the west rarely use their mother tongue 
as the only form of communication with close people. The same applies to the northsouth dichotomy. The Romani from the south use their mother tongue with close people more often, and in all communication situations, except with parents and relatives, there are statistically significant differences between the southeast and northwest of Serbia.

It is interesting to know whether the Romani in Serbia speak any language other than Romani. The data show that $3 / 4$ of the Romani in Serbia speak other language, $7.1 \%$ speak it poorly, and 3.1\% do not speak but understand another language (Figure 1). When asked about the language, $80.7 \%$ of the Romani named Serbian, but every fifth Romani respondent does not use Serbian, which confirms the problems with the Romani's social integration. Besides Serbian, the Romani most often speak English, German, Romanian and Albanian. Among those who speak two languages besides Romani, a combination of the above languages is most common (29\%). We believe that these are the Romani who spent some time in one of the countries where these languages are spoken, for instance in Kosovo and Metohija, as the languages of the majority.

We are interested in the use of Romani not in the linguistic perspective but rather in the sociological dimension, therefore we studied the attitudes of the Romani to the education of their children in Romani. As the question of language cannot be reduced to the linguistic one, it is not surprising that the respondents' responses were diverse as well as explanations of their attitudes. The majority of respondents (almost three quarters) consider their native language as one of the most important characteristics of their ethnic group, and despite the fact that the Law on the Protection of the Rights and Freedoms of National Minorities [10] allows education of minorities in their mother tongue under certain conditions less than a third of the Romani respondents (31.6\%) believe that their children should be educated in Romani at all levels of the education system, while $21.8 \%$ argue that this should only be the case for elementary education and $43.4 \%$ would not like their children to get education in Romani at all (Figure 2).

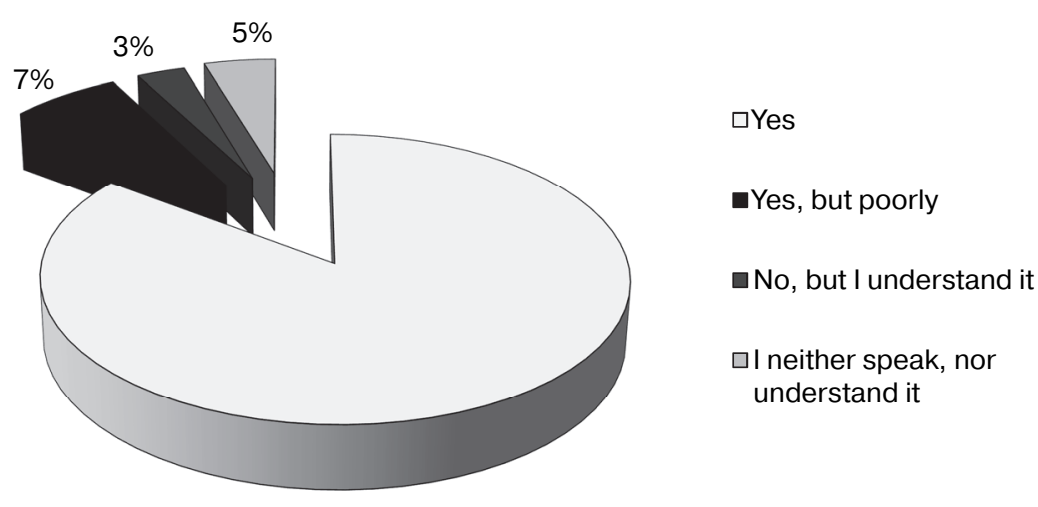

$85 \%$

Figure 1. Distribution of answers to the question whether respondents speak any language other than Romani 


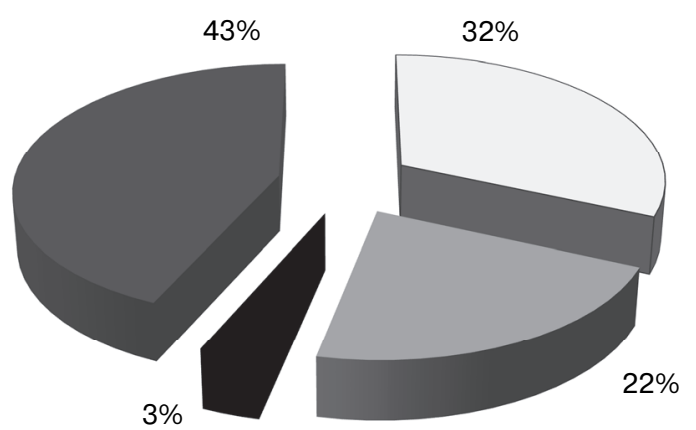

$\square$ Yes, at all education levels

Yes, but only in obligatory primary education

-Yes, but only until the end of secondary education

- No

Figure 2. Attitudes of the Romani to their children education in Romani

From the answers explaining the attitudes to the use of Romani in the education system it is clear that the use of a particular language is related to the efforts of individuals and groups to avoid discrimination on other grounds that linguistic. Therefore, the respondents believe that the use of Romani would be inadequate because they live in Serbia (77.4\%), do not benefit from having education in Romani (13.7\%), do not know Romani $(4.4 \%)$ or are not interested in such a possibility $(2 \%)$. This distribution of answers raises the question why the use of Romani in the education system is considered undesirable despite the fact that not knowing Serbian is a key obstacle for the education of the Romani [1], and that a great share of the Romani is in the category of the least educated [17; 19]. Scholars (P. Bourdieu) rightly argue that language is a tool for the 'battle' in education, economy, policy and ideology for by choosing a language speakers anticipate their own social position determined by the use of a particular language as a form of symbolic capital at their disposal. Thus, the Romani understand that, being a part of the state with the Serbian majority, they must acquire certain language competences because otherwise they would be excluded from various fields of life. Therefore, the Romani's position, and the awareness of it and of the language capital they have affect their linguistic behavior. They use different strategies to improve their social position - educate their children in the language of the majority to ensure that they do not differ much from the members of the majority by language competencies. Discrepancies between language practices at school and at home can be easily identified and can lead to the belief that, due to the lack of standard language competences, some people cannot get certain jobs (professions). The attitudes of the Romani to the education of children in Romani reflects the fact that the school system tends to reproduce the universal recognition of the language of the majority as the only legitimate and prestigious one.

Accordingly, benefits from advocating the rights of the Romani minority to be educated in their own language, which aims at preserving their ethnic identity, become 
a second-rank issue compared to acquiring an appropriate symbolic capital (language) transferable to other social fields. This is proved by the data showing that those who achieved better social inclusion use Romani considerably less. The inclusion in the education system, on the one hand, is a way to ensure social inclusion; on the other hand, educational institutions are key actors that reproduce existing power relations between cultures (and languages) of different social groups.

After years of work on the standardization of Romani, Romani activists in Serbia succeeded to introduce the Romani Language with the Elements of National Culture in elementary schools, thus, providing Romani equal rights with languages of other national minorities in Serbia. The Faculty of Philology in the Belgrade University opened language courses and provided opportunities for school teachers to get competences to teach this subject. These are important steps that can help Romani to be preserved. However, the language practices of the Romani in Serbia do not support the above mentioned measures of the state language policy of destigmatization. As long as there is a significant share of the members of the Romani community who refuse to use their mother tongue in private and public situations, and if this is especially true for the most educated part of the Romani community, there will remain a danger of losing this cultural part of the Serbian society and an authentic element of the cultural identity of the Romani. However, one should remember that the Romani language practices reflect their social position of a marginalized ethnic community, i.e. the responsibility lies not only on the Romani community. Such a situation will certainly continue not only due to the lack of interest of the Serbian majority to the Romani language, culture and tradition, but also due to the prevailing ghettoized lifestyle that prevent informal interaction of Romani and non-Romani populations. Certainly, positive perception of linguistic and cultural diversity can contribute to the preservation of Romani and other languages of minority communities. This is even more important for the social inclusion of the Romani, which implies language competences for different types of communication in Serbian.

\section{References}

[1] Analysis of the Application of Affirmative Measures in the Romani Education, and Recommendations for Improving Measures. Beograd; 2016 (In Serbian).

[2] Baucal A., Stojanović J. Indicators of Equal Access to the Quality Education for the Romani. Beograd; 2010 (In Serbian).

[3] Bourdieu P. Language and Symbolic Power. Cambridge; 1991.

[4] Đorđević D.B. Romanipen - the basis of cultural policy and cooperation of the Balkan Romani. Lj. Mitrović, D.B. Đorđević, D. Todorović (Eds.). Models of Cultural Policy in the Multicultural Societies of the Balkans and under the euro-integration. Niš; 2004 (In Serbian).

[5] Đorđević D. On Horseback with a Laptop in the Saddlebag — Introduction to Romani Studies. Niš; 2010 (In Serbian).

[6] Đurović B. Social segregation and ghettoized awareness of the Romani. M. Macura (Ed.). The Gypsies/Romani in the Past and Today. Beograd; 1996 (In Serbian). 
[7] Grenfell M. Bourdieu, language, and literacy. Reading Research Quarterly. 2009; 44 (4).

[8] Haliti B. Serbian-Romani Dictionary. Novi Sad; 2001.

[9] Jakšić B. Policy of changing the identity of the Romani in Serbia. T. Varadi, G. Bašić (Eds.). Changing the Identity, Culture and Language of the Romani under the Planned Social-Economic Integration. Beograd; 2012 (In Serbian).

[10] Law on the Protection of the Rights and Freedoms of National Minorities. Službeni list SRJ, br. 11/2002, Službeni list SCG, br. 1/2003, 72/2009, 97/2013 i 47/2018 (In Serbian).

[11] Lazar Ž., Koković D. Ethnic distance in Vojvodina (results of the research). Sociološki Pregled. 2005; 39 (3) (In Serbian).

[12] Miladinović S. Ethnic and social distance to the Romani. Sociološki Pregled. 2008; 42 (3) (In Serbian).

[13] Mitrovic A. At the Bottom: The Romani on the Poverty Line. Beograd; 1990 (In Serbian).

[14] Mitrović A. The position of the Romani in society - a possible approach to the research of the Romani population. M. Macura, V. Stanovčić (Ed.). The Position of Minorities in the Federal Republic of Yugoslavia. Beograd; 1996 (In Serbian).

[15] Mitrović A., Zajić G. Social status of the Romani in Serbia. The Romani in Serbia. Beograd; 1998 (In Serbian).

[16] Petrović J., Šuvaković U. Social distance of students of Serbia, Macedonia and Bulgaria to the Romani. Godišnjak za Sociologiju. 2016; 11 (14-15) (In Serbian).

[17] Raduški N. Social-demographic and ethnic characteristics of the Romani in Serbia. Sociološki Pregled. 2003; 37 (3-4) (In Serbian).

[18] Sokolovska V. On the research methodology and sample. V. Sokolovska (Ed.). Social and Cultural Potentials of the Romani in Serbia. Novi Sad; 2014 (In Serbian).

[19] Sokolovska V., Jarić I. Educational and economic status of the Romani in Serbia and its regional distribution. Sociološki Pregled. 2014; 48 (3) (In Serbian).

[20] Todorović D. The Romani in the Balkans and Serbia. Teme. 2011; 35 (4) (In Serbian).

DOI: $10.22363 / 2313-2272-2019-19-2-212-221$

\title{
Языковые практики цыган в Сербии: инклюзия или ответ на стигматизацию?*
}

\author{
Я. Петрович \\ Университет Ниша \\ ул. Кирилла и Мефодия, 2, Ниш, Сербия, 18000 \\ (e-mail: jasminafilfak1@gmail.com)
}

Представленные в статье данные являются частью исследовательского проекта «Социальный и культурный потенциал цыганского сообщества в Сербии», реализованного в 2014 году. Опрос был проведен на стратифицированной выборке в 1212 респондентов командой исследователей из четырех университетов Сербии. Одной из задач исследования было определение доминирующих языковых практик цыганского сообщества в Сербии. Автор описывает отношение сербских цыган к использованию разных языков в повседневном общении, а также сами их языковые практики, делая акцент

* ( С) Петрович Я., 2019.

Статья является частью проекта № 179013, реализованного при поддержке Министерства образования, науки и технологического развития Республики Сербия.

Статья поступила в редакциию 14.02.2019 2. 
на том, насколько важен цыганский язык для выражения цыганским сообществом собственной идентичности как этнического меньшинства, каковы социальные контексты для использования цыганского языка в повседневном общении и как оценивается важность подобной языковой компетентности цыганами - считается ли цыганский язык символическим капиталом в образовании, особенно учитывая представления цыганских родителей о его важности и их попытки обеспечить своим детям возможность получать образование на родном языке. Результаты опроса подтвердили гипотезу исследования, что отношение цыган к родному языку и их языковые практики являются отражением социального статуса данной группы как этнического меньшинства в сербском обществе. Соответственно, ее языковые практики обусловлены необходимость поддерживать свою этническую идентичность, а также неравномерным распределением социальной власти между сообществами, представляющими меньшинство и большинство. Таким образом, социальная власть (или ее отсутствие) придает легитимность использованию определенного языка в конкретных социальных ситуациях. В случае с цыганской этнической группой использование родного языка сведено лишь к сфере частного общения, причем некоторые цыгане отказываются от него и скрывают свою этническую принадлежность. Исследование подтвердило, что лингвистическая мимикрия - способ избежать социальной стигматизации.

Ключевые слова: Сербия; цыгане; языковые практики; идентичность; неравенство; стигматизация; инклюзия 